\title{
Variability and inheritance of fiber length and wilt resistance in a complex 4-5 specific and backcross hybridization of cotton
}

\author{
Sayfulla Boboyev, Gulnoza Toshpulatova, Ikrom Amanturdiev, Mirvakhob Mirakhmedov \\ Department of Biology, National University of Uzbekistan named after Mirzo Ulugbek, Tashkent, Uzbekistan
}

\begin{abstract}
In this paper presents data of researches about fiber length in the 4-5 species. The largest number of plants with the indicated analyzed trait in hybrid combinations, obtained with the participation of the variety Omad, appeared with a number of variations in fiber length at 35.0-36.0 $\mathrm{mm}$ and above. Investigation of 4-species hybrids of $F_{2}$ and back cross hybridization allowed some improvement in the average value of trait when compared with $F_{1}$. Despite the emergence of transgressive plants with fiber length 36.1-37.0 $\mathrm{mm}$ and above, the average trait of composite 5 species hybrids $\mathrm{F}_{2}$ remained almost at the level of $F_{1}$, i.e. $35.5-36.0 \mathrm{~mm}$. The greatest number of positive recombinants occurred in 5 species back crossing developed with the participation of Termez-31.
\end{abstract}

\section{Introduction}

In breeding of cotton, a wide variability of agronomy valuable traits and development of new forms can be achieved by using various hybridization methods. The hybridization process, howev-

Correspondence: Sayfulla Boboyev, Department of Biology, National University of Uzbekistan, Tashkent city, Uzbekistan.

Tel.: +998979944777

E-mail: guloy290795@gmail.com

Key words: Cotton; inheritance; generation; 4 and 5 specific hybrids; variability; hybridization; resistance.

Acknowledgements: This researches was supported by the Ministry of Innovative Development of the Republic of Uzbekistan, under scientific project OT-A-KX-2018-348.

Conflict of interest: The authors declare no conflict of interest.

Received for publication: 14 July 2020.

Revision received: 26 December 2020.

Accepted for publication: 2 February 2021.

${ }^{\circ}$ Copyright: the Author(s), 2021

Licensee PAGEPress, Italy

Journal of Biological Research 2021; $94: 9243$

doi:10.4081/jbr.2021.9243

This article is distributed under the terms of the Creative Commons Attribution Noncommercial License (by-nc 4.0) which permits any noncommercial use, distribution, and reproduction in any medium, provided the original author(s) and source are credited. er implemented, leads to the decoding of inheritance, allowing the formation of new flexible genotypes that have the ability to change and adapt to new growing conditions. Hybridization and selection are the main synthetic methods to develop new varieties, and success in this task depends largely on the choice of the method of crossing and the original forms of the genotypes. Therefore, the genetic variability of agronomic traits of crop plants must be increased, by involving genetic resistance to various stress factors, diseases and insects of original forms as well as wild relatives.

The emergence of new diseases, the distribution of insect populations and environmental degradation confront breeders with the challenge of increasing cotton production through the creation of varieties with early maturation, high yields, good yield and quality of fiber, and resistance to diseases and pests, as well as stress factors. The solution to these problems requires the improvement of the genetic basis of the evaluation of existing donors and the use of various methods of hybridization in order to create new genotypes that promote positive polygene recombination in a hybrid organism for use in applied cotton breeding.

The current problems of modern genetics and breeding are to assess the different hybridization methods that involve the genes that control economically valuable traits in order to identify optimal hybridization methods, allowing the development of new genotypes and genetically enriched recombinants. In this regard, research is underway to study the effectiveness of various complexities of hybridization and to generate unique genotypes of basic agronomy valuable traits and prove their effectiveness in creating genetically enriched and unique recombinants.

To solve the above problems, a wide study was deployed on the existing models of cultivated and wild species in the genetic collection of cotton using various hybridization techniques, the identification of donors and the creation of new genotypes for primary selection. However, some aspects of the complex interspecific hybridization of cotton, especially comparative studies to determine the effectiveness of interspecific hybrids obtained by crossing genetically different initial parents and the development of initial materials with complex agronomic traits for practical breeding are not comprehensively covered in the literature.

It is known that hybridization is a major source of genetic variation in populations. The resulting random chromosome segregation at meiosis, involving diverse parental forms, leads to the recombination of genetic materials. ${ }^{1}$ In the selection of crops, including cotton, different methods of interspecific hybridization are exploited to produce a wide variability in economically valuable traits and to develop nonexistent combinations.

Academicians Abdullaev et al. (1980) noted that the genus Gossypium L. has a huge variety of biological features. ${ }^{2}$ Most of these species are collected in genetic collections in Australia, Brazil, China, France (CIRAD), India, Pakistan, the USA and 
Uzbekistan. On the basis of cytogenetic differences, genus Gossypium is divided into eight groups of diploid genomes (from A to $\mathrm{G}$ and $\mathrm{K}$ ) and one tetraploid genome group. ${ }^{3}$ The same conclusion was reached by Grover et al. (2015) according to whom the genus Gossypium has 50 diploid species $(2 \mathrm{n}=2 \mathrm{x}=26)$ that can be differentiated cytogenetically into eight genome groups[ABCDEFGK], and seven allotetraploid species $(2 \mathrm{n}=4 \mathrm{x}=52){ }^{4}$

In recent years, it has been found that the genus Gossypium includes 46 diploid and 5 allotetraploid species. Uzbek scientists have similar observations. ${ }^{5}$ Many wild and ruderal forms have unique biological features that are absent or poorly expressed in cultivated species. A significant role is attributed to backcrossing hybridization for the improvement of agronomic traits. On the basis of hybridization, a composite triple hybrid ( $G$. hirsutum L. x G. herbaceum L.) x G. harknessi with a variety of G.hirsutum is valuable for bigger boll size, lint output and fiber length. ${ }^{6}$

In interspecific hybrids of cotton produced by crossing amphidiploids with different varieties starting with $F_{2}$, there is widespread transgressive variability for all quantitative traits, forming the basis for the selection of new genetic forms by selection. ${ }^{7}$ However, he noted that the most widespread variation in fiber output is observed in $\mathrm{F}_{2}-\mathrm{F}_{4}$, and in length and resistance to wilt in $\mathrm{F}_{4}-\mathrm{F}_{5}$. In composite interspecific hybrids $\mathrm{F}_{1}$, obtained with the participation amphidiploids G.thurberi Tod. x G.raimondii Ulbr. x G.hirsutum L., a formative process for agronomical valuable traits to the identification of transgressive forms in subsequent generations ${ }^{8}$ is observed due to wide segregation. He found that the fiber output and length in the studied composite interspecific hybrids had less variability compared to productivity and its components. Relatively high variation in fiber output was observed in $\mathrm{F}_{2}$, and in fiber length in $\mathrm{F}_{2}-\mathrm{F}_{3}$.

To solve this problem, the scientists of the republic carried out extensive research on transfer of wilt-resistant gene of wild cotton species to cultivars and there is a great success achieved. In particular, as a result of many years of research by academician S.M.Mirahmedov, wilt resistant varieties of series "Tashkent" were created. ${ }^{8-10}$ The sowing of these species on large areas of cotton planting have made a great contribution to the economy of our country.

However, environmental problems created in the cotton-growing areas for today promoted the appearance of new races of wilt disease. Consequently, it determines the relevance of scientific research and applied investigations in this direction. It is known that wild and semi-wild species, thanks to their distribution in various environmental conditions and long-term natural selection, have an abundance of genetic diversity that contains a lot of outstanding genes that can be used to implement such features as resistance to drought, disease and pest resistance, fine and strong fiber and others. ${ }^{11}$

\section{Materials and methods}

When creating complex $4 \mathrm{x}$ species and their back cross progenies - synthetic amphidiploid $\mathrm{F}_{0}\left(\mathrm{~F}_{1} \mathrm{~K}-28=\mathrm{F}_{1}\right.$ G.thurberi Tod. $\mathrm{x}$ G.raimondii Ulbr. x G.arboreum L.) x S - 4727, $\mathrm{F}_{0}\left(\mathrm{~F}_{1} \mathrm{~K}-28 \mathrm{~F}_{1} G\right.$. thurberi Tod. x G.raimondii Ulbr. x G.arboreum L.) x S - 6524 and variety Omad of species G. hirsutum L.

When creating complex $5 \mathrm{x}$ species and their back cross progenies $4 \mathrm{x}$ genomic hybrid - $\mathrm{F}_{0}\left(\mathrm{~F}_{1} \mathrm{~K}-28 \mathrm{~F}_{1}\right.$ G.thurberi Tod. $\mathrm{x}$ G.raimondii Ulbr. x G.arboreum L. ) x S $-4727, \mathrm{~F}_{0}\left(\mathrm{~F}_{1} \mathrm{~K}-28 \mathrm{~F}_{1}\right.$ G.thurberi Tod. x G.raimondii Ulbr. X G.arboreum L.) x S- 6524 and the variety Termez -31 of the species G.barbadense L. All the experimen- tal data were subjected to statistical processing according to Dospekhov (1985).

The incidence of wilt in cotton was taken into account three times during the growing season of plants: August 15 and September 1-15. The degree of resistance to diseases was determined visually and by breaking the plant stem (Figure 1).

Research work was carried out in 2018-2019, in particular, field and artificial experiments were carried out at the National University of Uzbekistan and at the Research institute of cotton breeding and seed production.

\section{Results and Discussion}

The staple length of the original cultivars was longer than that of amphidiploids $\left[\left(\mathrm{F}_{1}\left(\mathrm{~F}_{1} G\right.\right.\right.$. thurberi Tod. $\mathrm{x}$ G.raimondii Ulbr. $\mathrm{x}$ G.arboreum L.) x S-4727 (G.hirsutum L.)] and $\left[\mathrm{F}_{1}\left(\mathrm{~F}_{1}\right.\right.$ G.thurberi Tod. x G.raimondii Ulbr. x G.arboreum L.) x S-6524 (G.hirsutum L.)]. The longest fiber length $(36,6 \mathrm{~mm})$ was observed in variety Termez31 and the shortest one $(33,0 \mathrm{~mm})$ in amphidiploids $\left[\mathrm{F}_{1}\left(\mathrm{~F}_{1}\right.\right.$ G.thurberi Tod. x G.raimondii Ulbr. x G.arboreum L.) x S-4727 (G.hirsutum L.)]. It was concluded that two backcrosses, unlike one, with the variety Omad improved average fiber length and variability. The largest number of plants with values is located in the middle and the right classes in an ordered series, and the average level of initial 4-species hybrid amphidiploids, i.e. 33,1-33,9 mm.

In 5-species hybrids, the average fiber length was $2-3 \mathrm{~mm}$ better than in the $4 \mathrm{x}$ species. The largest number of plants with the indicated analyzed trait in hybrid combinations, obtained with the participation of the Omad variety, appeared with a number of variations in fiber length at 35,0-36,0 $\mathrm{mm}$ and above. Investigation of 4-species hybrids of $F_{2}$ and back cross hybridization allowed some improvement in the average value of trait when compared with $F_{1}$. Despite the emergence of transgressive plants with fiber length 36,1-37,0 $\mathrm{mm}$ and above, the average trait of composite 5 species hybrids $\mathrm{F}_{2}$ remained almost at the level of $F_{1}$, i.e. $35.5-36.0 \mathrm{~mm}$. The greatest

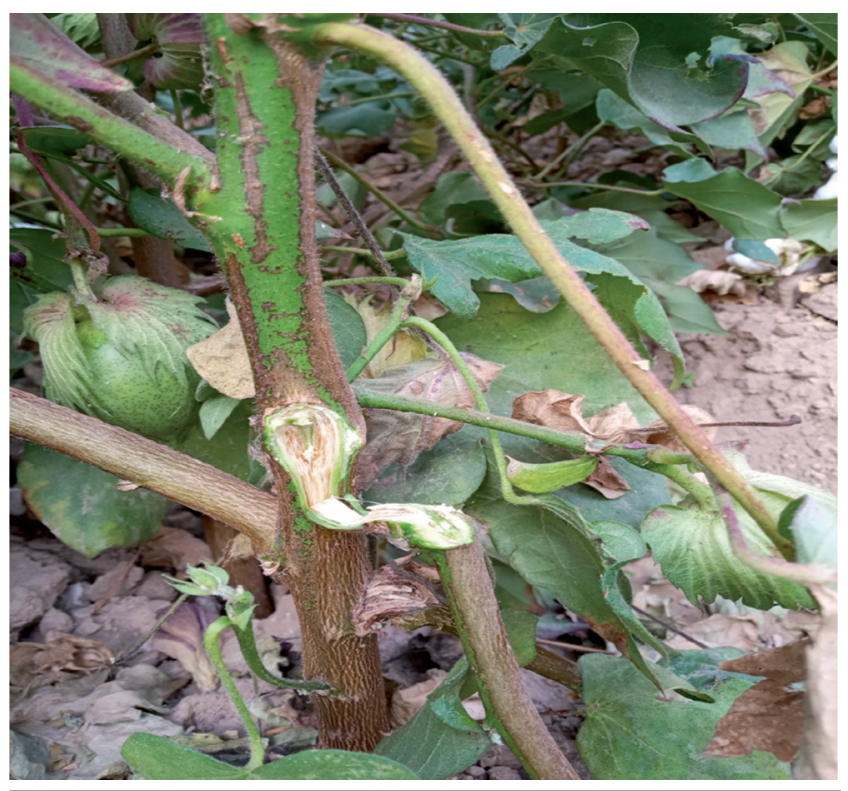

Figure 1. Characteristic vascular discoloration of a cotton stem infected by Fusarium oxysporum f. sp. Vasinfectum. 
number of positive recombinants occurred in 5 species back crossing developed with the participation of Termez-31.

The average value of staple length in complex 4-5 species hybrids was observed to significantly improve among progenies $\mathrm{F}_{3}$ (Table 1).

As a result, the average value of four species hybrids is $34,7 \mathrm{~mm}$, from one and two-fold and backcrosses $\mathrm{F}_{1}\left\{\mathrm{BC}_{1}\left[\left(\mathrm{~F}_{1} \mathrm{~K}-28 \times \mathrm{S}-6524\right) \mathrm{x}\right.\right.$ Omad $] x$ Omad $\}, F_{1}\left\{B_{2}\left[\left(F_{1} K-28 \times\right.\right.\right.$ S-6524)x Omad $] x$ Omad $\}$ at $35.0 \mathrm{~mm}$. It should be noted that the highest average values of the trait (36.0 mm and above) were detected in 5 back cross species hybridization. This data will likely be explained by the influence encountered by recombinants with a length $40.0 \mathrm{~mm}$ and above in $\mathrm{F}_{3}$.

However, the performance of the standard deviation and coefficient of variation in $\mathrm{F}_{3}$ hybrids were lower, indicating a relatively rapid stabilization of the trait. The above conclusion is confirmed by the average value of the attribute staple length in composite hybrids $\mathrm{F}_{4}$, due to the appearance of a large number of plants in the right classes of variation series, resulting in mean values of the analyzed trait ranging from 35.0 to $35.5 \mathrm{~mm}$ in composite 4 species hybrids and back crosses. Unlike the $4 \mathrm{x}$ species hybrids, at 5 species mean values of the attribute staple length $(36.4-37.0 \mathrm{~mm})$ were at a higher level. The highest average value of staple length $(37.0 \mathrm{~mm})$ was observed in 5 species back cross hybridization combination $\mathrm{F}_{4}\left\{\left(\mathrm{BC}_{1}\left(\mathrm{~F}_{1} \mathrm{~K}-28\right) \times \mathrm{C}-6524\right) \times\right.$ Termez-31 $\mathrm{x}$ Termez-31\}. The five species hybrids and their backcrosses highlighted recombinants with fiber length of $40.0 \mathrm{~mm}$ and above, which are being studied in the control nursery of the laboratory.

Study of the variability of the attribute "staple fiber" hybrids $\mathrm{F}_{1}-\mathrm{F}_{4}$ shows that composite 4-5 species hybridization promotes positive transgression. The highest variability in a composite trait hybridization observed in composite 5 species hybrids, which indicates the significant contribution of long-genotype component crossing trait on display. The occurrence of plants with positive transgression composite interspecific hybridization is mainly observed in $F_{3}$, and since $F_{4}$, is stabilized on the basis, as in 4 species, and 5 species hybrids.

Further, wilt-resistant plants have been studied in detail at the newly created polygenomatic and backcrossing interspecies cotton hybrids. The results of research of the parental varietes indicate the resistance to wilt of Omad varietiy in total of $12.6 \%$ and $5.53 \%$ in the strong degree (Table 2). The most intense susceptibility was observed in grade differentiator C-4727 - 34.3\% in total and $15.6 \%$ to a great extent. On the basis of the average values of the characteristic "tolerant to $V$. dahliae" in complex interspecific hybrids we can talk about the impact of the original genotype of cultivars, that is, depending on the stability of their aforementioned different races of the pathogen. This is confirmed by the highest affection of wilt of 4 species hybrid $F_{1}(K-28) \times$ S-4727, obtained with the participation of the first race of the unstable grade S-4727 in general, and to a great extent as compared with a complex of 4 species hybrid $F_{4}\left(F_{1} K 28\right)$ $\mathrm{x}$ S-6524, created with the participation of the second race of tolerant varieties $V$. dahliae S-6524. Affection of these hybrids, a total degree was 7,4 \% and $19,7 \%$ and a strong $2,2 \%$ and 3,6 \%, respectively. As a result of two-hold hybridization with Omad variety of form $G$. hirsutum L., the affection of wilt is decreased in general and and a large extent, which is apparently due to the relatively high tolerance to the aforesaid pathogen (Table 2).

The conclusion, which refers to the efficiency of selection of resistant plants to wilt in the early generations of interspecies hybrids, created with the participation of grade S-6524, is confirmed by the values of $F_{6}$ hybrids. It should be noted, that unlike other agronomic characteristics on resistance to wilt, strong differences are not observed depending on genotype and the number of backcrosses. This is confirmed by the appearance of the most tolerant and relatively unstable families and among complex interspecies hybrids and backcrossing $\mathrm{F}_{6}$. Among the plants of $\mathrm{F}_{6}$ combination $\left[\left(\mathrm{F}_{1} \mathrm{~K}-28\right.\right.$ x S-6524) x Omad)] plants were identified with the highest rates of plant susceptibility, both general and a strong degree of affection by wilt. At the $\mathrm{F}_{6}$ the value of the coefficient of variation in the variational series on the analyzed attributes was decreased, especially in the hybrids $\left.\left\{\mathrm{BC}_{2}\left[\left(\mathrm{~F}_{1} \mathrm{~K}-28 \times \mathrm{S}-4727\right) \times \mathrm{Omad}\right)\right] \times \mathrm{Omad}\right\}$ and $\left\{\mathrm{BC}_{2}\right.$ $\left.\left.\left[\left(\mathrm{F}_{1} \mathrm{~K}-28 \times \mathrm{S}-6524\right) \times \mathrm{Omad}\right)\right] \times \mathrm{Omad}\right\}$.

Thus, by studying the tolerance characteristic in $V$. dahliae complex species hybrids 4-5 obtained with involving amphidiploid $\mathrm{F}_{1} \mathrm{~K}-28$ at wilt background can be it concluded, that it is a valuable donor of stability and it can be recommended together with hybrids

Table 1. Variability in staple length in 4-5 species and backcross hybrids, ( $\mathrm{mm}$ ).

\begin{tabular}{|c|c|c|c|c|c|c|c|c|c|c|c|c|c|c|}
\hline Varieties and hybrids & n & $\begin{array}{l}30.1- \\
31.0\end{array}$ & $\begin{array}{l}31.1- \\
32.0\end{array}$ & $\begin{array}{l}32.1- \\
33.0\end{array}$ & $\begin{array}{r}33.1- \\
34.0\end{array}$ & $\begin{array}{l}\text { One } 11 \\
34.1- \\
35.0\end{array}$ & $\begin{array}{c}\mathrm{m} \text { ra } \\
35.1- \\
36.0\end{array}$ & $\begin{array}{l}\text { nge } \\
36.1- \\
37.0\end{array}$ & $\begin{array}{l}37.1- \\
38.0\end{array}$ & $\begin{array}{l}38.1- \\
39.0\end{array}$ & $\begin{array}{ll}39.1-40.1- \\
40.0 & 41.0\end{array}$ & $M \pm m$ & SD & CV \\
\hline 1. Omad & 37 & & & 2 & 5 & 11 & 12 & 7 & & & & $34.9 \pm 0.2$ & 1.1 & 3.2 \\
\hline 2. Termez-31 & 36 & & & & & 1 & 5 & 15 & 9 & 3 & 3 & $36.6 \pm 0.2$ & 1.2 & 3.2 \\
\hline 3. $\mathrm{F}_{3}\left[\left(\mathrm{~F}_{1} \mathrm{~K}-28\right) \times \mathrm{S}-6524\right.$ & 66 & & 2 & 5 & 13 & 25 & 10 & 7 & 4 & 2 & & $34.7 \pm 0.3$ & 1.5 & 4.6 \\
\hline 4. $F_{3}\left[\left(F_{1} K-28\right) \times S-4727\right.$ & 76 & 2 & 3 & 4 & 14 & 22 & 14 & 9 & 5 & 3 & & $34.7 \pm 0.2$ & 1.6 & 4.8 \\
\hline \multicolumn{15}{|l|}{4 species hybrids and backcrosses } \\
\hline 5. $\mathrm{F}_{3} \mathrm{BC}_{1}\left[\left(\mathrm{~F}_{1} \mathrm{~K}-28 \times \mathrm{S}-6524\right) \times \mathrm{Omad}\right]$ & 85 & & 2 & 6 & 17 & 14 & 22 & 11 & 10 & 2 & & $35.0 \pm 0.2$ & 1.6 & 4.6 \\
\hline 6. $\mathrm{F}_{3} \mathrm{BC}_{1}\left[\left(\mathrm{~F}_{1} \mathrm{~K}-28 \times \mathrm{S}-4727\right) \times \mathrm{Omad}\right]$ & 112 & 1 & 2 & 9 & 12 & 23 & 35 & 20 & 8 & 4 & & $35.1 \pm 0.1$ & 1.6 & 4.5 \\
\hline 7. $\mathrm{F}_{3} \mathrm{BC}_{2}\left\{\left[\left(\mathrm{~F}_{1} \mathrm{~K}-28 \times \mathrm{S}-6524\right) \times \mathrm{Omad}\right] \times \mathrm{Omad}\right\}$ & 112 & & 4 & 6 & 16 & 23 & 31 & 20 & 8 & 4 & & $35.1 \pm 0.1$ & 1.4 & 4.0 \\
\hline 8. $\mathrm{F}_{3} \mathrm{BC}_{2}\left\{\left[\left(\mathrm{~F}_{1} \mathrm{~K}-28 \times \mathrm{S}-4727\right) \times \mathrm{Omad}\right] \times \mathrm{Omad}\right\}$ & 114 & & 3 & 7 & 11 & 32 & 35 & 16 & 6 & 3 & & $35.0 \pm 0.1$ & 1.4 & 4.1 \\
\hline
\end{tabular}

\begin{tabular}{|c|c|c|c|c|c|c|c|c|c|c|c|c|c|}
\hline 9. $\mathrm{F}_{3}\left[\left(\mathrm{~F}_{1} \mathrm{~K}-28 \times \mathrm{S}-6524\right) \times \mathrm{Termez}-31\right]$ & 85 & 2 & 4 & 9 & 13 & 28 & 14 & 11 & 3 & 2 & $36.5 \pm 0.2$ & 1.7 & 4.5 \\
\hline 10. $\mathrm{F}_{3}\left[\left(\mathrm{~F}_{1} \mathrm{~K}-28 \times \mathrm{S}-4727\right) \times \mathrm{Termez}-31\right]$ & 95 & 2 & 6 & 5 & 23 & 32 & 13 & 9 & 5 & 3 & $36.0 \pm 0.2$ & 1.7 & 4.6 \\
\hline 11. $\mathrm{F}_{3} \mathrm{BC}_{1}\left\{\left[\left(\mathrm{~F}_{1} \mathrm{~K}-28 \mathrm{xS}-6524\right) \times\right.\right.$ Termez-31]x Termez-31 $\}$ & 88 & 4 & 4 & 9 & 13 & 20 & 18 & 6 & 4 & 2 & $36.8 \pm 0.2$ & 1.8 & 4.9 \\
\hline 12. $\mathrm{F}_{3} \mathrm{BC}_{1}\left\{\left[\left(\mathrm{~F}_{1} \mathrm{~K}-28 \mathrm{xS}-4727\right) \times\right.\right.$ Termez-31] $\mathrm{x}$ Termez-31 $\}$ & 102 & 1 & 5 & 11 & 13 & 24 & 16 & 9 & 6 & 2 & $36.5 \pm 0.2$ & 1.7 & 4.7 \\
\hline
\end{tabular}


Table 2. Affection of wilt of complex interspecies, backcross hybrids and conventional varieties to compare their stability, \%.

\begin{tabular}{|c|c|c|c|c|c|c|}
\hline \multirow[t]{3}{*}{ Varieties and hybrids } & \multicolumn{6}{|c|}{ Affection of wilt } \\
\hline & \multicolumn{3}{|c|}{ At the overall degree } & \multicolumn{3}{|c|}{ At the strong degree } \\
\hline & $\mathrm{M} \pm \mathrm{m}$ & S & V \% & $\mathrm{M} \pm \mathrm{m}$ & S & V \% \\
\hline \multicolumn{7}{|c|}{ The hybrids involved as maternal form } \\
\hline $\mathrm{F}_{1}\left(\mathrm{~F}_{1} \mathrm{~K}-28\right) \times \mathrm{S}-6524$ & $7.4 \pm 1.3$ & 3.5 & 31.2 & $2.2 \pm 1.1$ & 2.0 & 15.7 \\
\hline $\mathrm{F}_{1}\left(\mathrm{~F}_{1} \mathrm{~K}-28\right) \times \mathrm{S}-4727$ & $19.7 \pm 1.5$ & 4.2 & 34.3 & $3.6 \pm 1.3$ & 2.8 & 22.5 \\
\hline \multicolumn{7}{|c|}{ Varieties involved in the creation of complex and interspecies and backcrossing hybrids } \\
\hline Omad (G. hirsutum L.) & $12.6 \pm 1.8$ & 2.0 & 11.4 & $5.5 \pm 0.5$ & 1.9 & 10.4 \\
\hline S-4727 (G. hirsutum L.) & $34.3 \pm 1.6$ & 2.3 & 18.2 & $15.6 \pm 1.9$ & 1.6 & 17.3 \\
\hline \multicolumn{7}{|c|}{$\mathrm{F}_{4}$ generation of obtained complex interspecies and backcrossing hybrids } \\
\hline$\left[\mathrm{BC}_{1}\left(\mathrm{~F}_{1} \mathrm{~K}-28 \mathrm{~S}-6524\right)\right.$ Omad $]$ & $12.9 \pm 1.2$ & 2.5 & 27.1 & $1.7 \pm 1.0$ & 1.4 & 34.3 \\
\hline$\left[\mathrm{BC}_{1}\left(\mathrm{~F}_{1} \mathrm{~K}-28 \mathrm{~S}-4727\right) \quad \mathrm{Omad}\right]$ & $17.0 \pm 2.3$ & 5.3 & 30.3 & $7.2 \pm 1.8$ & 2.6 & 28.4 \\
\hline$\left\{\mathrm{BC}_{2}\left[\left(\mathrm{~F}_{1} \mathrm{~K}-28 \mathrm{~S}-6524\right)\right.\right.$ Omad $\left.] \quad \mathrm{Omad}\right\}$ & $9.7 \pm 2.0$ & 2.1 & 15.2 & $1.4 \pm 0.9$ & 1.4 & 21.6 \\
\hline$\left\{\mathrm{BC}_{2}\left[\left(\mathrm{~F}_{1} \mathrm{~K}-28\right.\right.\right.$ S-4727) Omad $]$ Omad $\}$ & $10.9 \pm 1.8$ & 2.7 & 22.4 & $2.6 \pm 0.8$ & 3.6 & 18.4 \\
\hline \multicolumn{7}{|c|}{$F_{6}$ generation of obtained complex interspecies and backcrossing hybrids } \\
\hline$\left[\mathrm{BC}_{1}\left(\mathrm{~F}_{1} \mathrm{~K}-28 \mathrm{~S}-6524\right) \quad\right.$ Omad $]$ & $6.9 \pm 1.2$ & 2.3 & 28.4 & $1.2 \pm 0.7$ & 1.2 & 17.3 \\
\hline$\left[\mathrm{BC}_{1}\left(\mathrm{~F}_{1} \mathrm{~K}-28\right.\right.$ S-4727) $\left.\mathrm{Omad}\right]$ & $10.1 \pm 2.4$ & 3.0 & 25.2 & $1.4 \pm 1.9$ & 2.2 & 20.1 \\
\hline$\left\{\mathrm{BC}_{2}\left[\left(\mathrm{~F}_{1} \mathrm{~K}-28 \mathrm{~S}-6524\right) \quad 0 \mathrm{mad}\right] \quad\right.$ Omad $\}$ & $5.1 \pm 0.7$ & 1.3 & 14.3 & $0.5 \pm 0.1$ & 0.5 & 8.2 \\
\hline$\left\{\mathrm{BC}_{2}\left[\left(\mathrm{~F}_{1} \mathrm{~K}-28\right.\right.\right.$ S-4727) $\left.0 \mathrm{mad}\right] \quad$ Omad $\}$ & $6.5 \pm 0.8$ & 1.7 & 12.1 & $1.2 \pm 0.3$ & 1.4 & 10.9 \\
\hline \multicolumn{7}{|c|}{ Standard varieties for comparing sustainability indicators in affection of wilt } \\
\hline Tashkent-6 (G. hirsutum L.) & $12.6 \pm 1.5$ & 2.2 & 19.3 & $6.3 \pm 1.0$ & 2.4 & 19.5 \\
\hline Namangan-77 (G. hirsutum L.) & $20.4 \pm 2.1$ & 3.2 & 23.4 & $9.2 \pm 1.7$ & 2.5 & 17.4 \\
\hline
\end{tabular}

created by its participation to be included in genetic and breeding research to create original, hybrid and breeding material for breeding for tolerant to $V$. dahliae.

\section{Conclusions}

A comparative study of the variability of the characteristic of fiber length at the composite 4-5 species hybridization found that $\mathrm{F}_{1}-\mathrm{F}_{4}$ demonstrated positive transgression. The highest variability in a composite hybridization was observed among the composite 5 species hybrids, which indicates the significant contribution of long staple genotypes involved in crossing.

It is determined that at composite $4-5$ species hybridization the occurrence of the largest number of plants with positive transgression of fiber length is mainly observed in $\mathrm{F}_{3}$, and starting $\mathrm{F}_{4}$ is stabilized in both 4 species and 5 species hybrids.

Wild species of cotton, as well as complex polygenomatic hybrids obtained featuring amphidiploid $\mathrm{F}_{1} \mathrm{~K}-28$ are valuable donors of resistance to wilt, that allows to recommend them for use as a breeding material for practical breeding.

\section{References}

1. Abdullaev AA, Klyat VP, Rizaeva SM. Evolutionary and historical aspects of natural and artificial selection to improve early maturity of cotton. Evolutionary and selection aspects, early maturity and adaptability of cotton and other crops: Proceedings of an international scientific conference. Tashkent, Uzbekistan Academy of Sciences: FAN, 2005:9-12. (Russian).

2. Abdullaev AA, Omelchenko MB, Lazereva N. Potential for creating genus Gossypium- base promising cotton varieties. Khlopkovodstvo 1980;8:29-31. (Russian).

3. Endrizzi JE, Turcotte EL, Kohel RJ. Genetics, cytology and evolution of gossypium. Adv Gen 1985;23:271-375.

4. Grover CE, Gallagher JP, Jareczek JJ, et al. Re-evaluating the phylogeny of allopolyploid Gossypium L. Mol Phylogenet Evol 2015;92:45-52.

5. Arutyunova L, Pulatov M. Interspecific hybridization - create the original source material for breeding and replenish the gene pool of cotton. Genetika, selektsiya i semenovodstvo khlopchatnika i lyutserny, Tashkent: 1989:43-50. (Russian).

6. Babamuratov H. Inheritance of some morphological and agronomic traits in the progeny of a three-specific cotton hybrids. Ph.D. Thesis in Cotton Science, Tashkent: 1982:24. (Russian)

7. Mirakhmedov S.M. Razrabotka metoda vyvedeniya viltoustoychivykh sortov khlopchatnika i vnedreniye ikh v proizvodstvo. Genetika khlopchatnika, Tashkent: 1972:89-97.

8. Namazov Sh. E. Character formation in the progeny of interspecific hybrid G. thurberi Tod.xG.raimondii Ulbr. by crossing them with varieties of specie G. hirsutumL. Ph.D. Thesis in Cotton Science, Tashkent: 1996:24. (Russian).

9. Pulatov M. Interspecific hybridization in cotton genetics and breeding (Review), Tashkent: 1993:22.

10. Mirakhmedov SM. Razrabotka metoda vyvedeniya viltoustoychivykh sortov khlopchatnika i vnedreniye ikh v proizvodstvo. Genetika khlopchatnika, Tashkent: 1972:89-97.

11. Dospekhov BA. Metodika polevogo opyta. Moscow: Kolos, 1985:351. (Russian). 